\title{
KERAGAAN PERTUMBUHAN KELEMBAK DARI BERBAGAI DAERAH DI JAWA TENGAH
}

\author{
Nurul Husniyati Listyana, Dyah Subositi, Widyantoro \\ Balai Besar Penelitian dan Pengembangan Tanaman Obat dan Obat Tradisional \\ Jalan raya Lawu No 11 Tawangmangu, Karanganyar, Jawa Tengah \\ email: nurul.haydar@gmail.com
}

\begin{abstract}
Rhubarb is a plant originating from the Central China plain which is widely used for traditional medicine. The purpose of this research is to know the growth of nine rhubarb accession from various regions in Central Java. The result of this research is nine accessi of rhubarb divided into 2 variants that is javanese rhubarb and jamu rhubarb which then planted at same location shows different growth. Jamu rhubarb show higher growth than Javanese rhubarb.
\end{abstract}

Key words: rhubarb, accession, growth guidance

\section{PENDAHULUAN}

Kelembak (Rheum officinale Baill.) sering dikenal dengan nama Rhubarb. Tanaman ini berasal dari daratan Tengah China kemudian menyebar ke Eropa dan daerah sub tropik lainnya (Kuhl \& DeBoer, 2008). Di Indonesia tanaman ini hanya ditemukan tumbuh di daerah pegunungan pada tanah yang gembur dan subur. Pusat penanaman kelembak yaitu di Dataran Tinggi Dieng. Kelembak dapat diperbanyak dengan menggunakan biji, namun secara umum menggunakan pemisahan tanaman (splitting) (Kementerian Kesehatan RI, 2012).

Akar kelembak mengandung aloe-imodin, rhein, emodin dan physcion (Zhao N, et al., 2014), anthrones dan glikosida, stilbenes, sakarida, tanin dan sebagainya (Sheng, et al., 2011). Dalam beberapa tahun terakhir ditemukan komponen baru seperti sulfemodin8-O-b-D-glukosida, revandchinone-1, revandchinone-3, revandchinone-4, 6-methylrhein dan 6-methyl aloe-emodin (Ahmad, et al., 2013).

Kelembak berkhasiat memperbaiki fibrosis tubulointerstitial pada ginjal tikus $5 / 6 \mathrm{Nx}$, dengan mengurangi IS yang berlebihan dan mengurangi stres oksidatif ginjal dan cedera inflamasi (Lu, et al., 2015). Selain itu kelembak mempertahankan penghalang mukosa usus melalui mengatur flora usus dan menghambat respon inflamasi usus pada tikus dengan SAP (Yao, et al., 2015), memainkan peran protektif pada tikus dengan BPD yang diinduksi oleh hiperoksia melalui penghambatan respon inflamasi dan stres oksidatif (Cui, et al., 2017; Ling Yin, et al., 2018). Pemberian ekstrak akar kelembak (Rheum officinale Baill) dapat meningkatkan jumlah sel fibroblas pada penyembuhan luka gingiva tikus Wistar. Jumlah sel fibroblas mengalami peningkatan mulai dari hari ke-3 
sampai hari ke-7 (Yasha \& Prihartiningsih, 2012).

Emodin adalah salah satu bahan aktif utama dari Rheum palmatum, dan memiliki efek anti-inflamasi, anti-bakteri, anti-virus dan lainnya. Dalam beberapa tahun terakhir, ini menimbulkan kekhawatiran karena memiliki efek anti-tumor yang signifikan dengan toksisitas rendah (Fu Lin, et al., 2015). Emodin memiliki spektrum properti farmakologi yang luas, termasuk aktivitas antikanker, hepatoprotektif, antiinflamasi, antioksidan dan antimikroba. Namun, emodin juga dapat menyebabkan hepatotoksisitas, keracunan ginjal dan keracunan reproduksi, terutama dalam dosis tinggi dan penggunaan jangka panjang. Studi farmakokinetik menunjukkan bahwa emodin memiliki bioavailabilitas oral yang buruk pada tikus karena glukuronasinya yang luas (Dong, et al., 2016). Emodin dapat meringankan derajat fibrosis hati dengan mengurangi infiltrasi monosit Grlhi. Hasil ini menunjukkan bahwa emodin adalah kandidat yang menjanjikan untuk mencegah dan mengobati fibrosis (An Zhao, et al., 2018). Emodin secara signifikan mengurangi pembentukan adhesi intraabdomen dalam model tikus (Wei, et al., 2017), melindungi hati tikus dari $\mathrm{CCl}$ (4) induced fibrogenesis dengan menghambat aktivasi HSC, merupakan agen antifibrotik terapeutik untuk pengobatan fibrosis hati (Xian Dong, et al., 2009).

Di Indonesia, selain digunakan sebagai bahan campuran pembuatan rokok, kelembak juga digunakan sebagai ramuan antikolesterol dan pelangsing. Namun demikian penelitian mengenai kelembak masih sangat terbatas. Berdasarkan informasi dari Kantor Informasi Penyuluhan Pertanian dan Kehutanan Kabupaten Magelang, terdapat 3 jenis kelembak yaitu kelembak jawa, kelembak jamu dan kelembak jombor. Penelitian ini bertujuan untuk mengetahui keragaan pertumbuhan sembilan aksesi kelembak dari berbagai daerah di Jawa Tengah.

\section{BAHAN DAN METODE PENELITIAN}

Sebanyak sembilan aksesi kelembak ditanam pada kondisi lahan yang sama dan diamati keragaan pertumbuhannya. Aksesi kelembak yang diamati pertumbuhannya terdiri dari : Jamu Mangli, Jamu Adipuro, Jamu Butuh, Jamu Tlogodlingo, Jawa Temanggung, Jawa Mangli, Jawa Adipuro, Jawa Butuh, Jawa Wonosobo

Perbanyakan dilakukan dengan menggunakan siwilan (vegetatif) menggunakan akar. Setiap individu dibuat menjadi 3-5 bibit. Pembibitan dilakukan selama 6 minggu. Selanjutnya bibit ditanam di lahan terbuka dengan jarak tanam 100x100 cm. Karakterisasi dilakukan dengan melakukan pengamatan pada sampel kelembak dan dilakukan selama 6 bulan mulai bulan Juni (BST 1). Pengamatan yang dilakukan meliputi variabel pertumbuhan yang terdiri dari tinggi tanaman, lebar tanaman, panjang tangkai daun, keliling tangkai daun, jumlah daun, jumlah anakan, 
panjang daun, dan lebar daun. Sedangkan untuk karakter morfologi yang diamati yaitu warna daun dan warna tangkai daun.

\section{HASIL DAN PEMBAHASAN}

Berikut hasil pengamatan karakter pertumbuhan Kelembak:

1. Tinggi tanaman
Tinggi tanaman masing-masing aksesi kelembak diamati selama 6 bulan. Berikut data hasil pengamatan tinggi tanaman kelembak selama 6 bulan.

Berdasarkan hasil pengamatan di atas terlihat bahwa kelembak jamu tlogodlingo

Tabel 1. Data pengamatan tinggi tanaman aksesi kelembak (High observation data of rhubarb accession plant)

\begin{tabular}{lrrrrrr}
\hline \multicolumn{1}{c}{ AKSESI } & \multicolumn{6}{c}{ BST KE- } \\
\cline { 2 - 7 } & \multicolumn{1}{c}{$\mathrm{I}$} & \multicolumn{1}{c}{$\mathrm{II}$} & \multicolumn{1}{c}{ III } & \multicolumn{1}{c}{ IV } & \multicolumn{1}{c}{$\mathrm{V}$} & \multicolumn{1}{c}{ VI } \\
\hline JAMU MANGLI & $4.24 \mathrm{bc}$ & $23.88 \mathrm{ab}$ & $34.26 \mathrm{a}$ & $36.18 \mathrm{a}$ & $35.04 \mathrm{ab}$ & $40.14 \mathrm{ab}$ \\
JAMU ADIPURO & $5.14 \mathrm{bc}$ & $28.24 \mathrm{ab}$ & $29.28 \mathrm{a}$ & $34.82 \mathrm{a}$ & $35.3 \mathrm{ab}$ & $42.36 \mathrm{~b}$ \\
JAMU BUTUH & $4.02 \mathrm{c}$ & $27.98 \mathrm{ab}$ & $29.62 \mathrm{a}$ & $33.98 \mathrm{a}$ & $34.34 \mathrm{ab}$ & $48.1 \mathrm{ab}$ \\
JAMU TLOGODLINGO & $4.76 \mathrm{bc}$ & $40.82 \mathrm{c}$ & $37.62 \mathrm{a}$ & $41.46 \mathrm{a}$ & $38.2 \mathrm{~b}$ & $58.12 \mathrm{c}$ \\
JAWA TEMANGGUNG & $1.72 \mathrm{a}$ & $31.74 \mathrm{a}$ & $33.8 \mathrm{a}$ & $49.37 \mathrm{a}$ & $39.58 \mathrm{a}$ & $48.16 \mathrm{a}$ \\
JAWA MANGLI & $3.72 \mathrm{a}$ & $28.36 \mathrm{~b}$ & $38.74 \mathrm{a}$ & $41.18 \mathrm{a}$ & $33.74 \mathrm{~b}$ & $39.16 \mathrm{~b}$ \\
JAWA ADIPURO & $5 \mathrm{c}$ & $28.24 \mathrm{ab}$ & $34.64 \mathrm{a}$ & $38.1 \mathrm{a}$ & $36.32 \mathrm{~b}$ & $36.62 \mathrm{a}$ \\
JAWA BUTUH & $1.72 \mathrm{bc}$ & $22.06 \mathrm{ab}$ & $35.3 \mathrm{a}$ & $34.24 \mathrm{a}$ & $26.82 \mathrm{ab}$ & $33.24 \mathrm{ab}$ \\
JAWA WONOSOBO & $3.1 \mathrm{ab}$ & $28.2 \mathrm{ab}$ & $36.66 \mathrm{a}$ & $38.68 \mathrm{a}$ & $32.66 \mathrm{ab}$ & $38.42 \mathrm{a}$
\end{tabular}

Keterangan: angka-angka yang diikuti huruf berbeda pada kolom yang sama menunjukkan ada beda nyata pada uji DMRT 0.05 (Description: the numbers followed by different letters in the same column show there is a real difference in the DMRT 0.05 test)

Tabel 2. Lebar tanaman (diameter) masing-masing aksesi kelembak (Plant width (diameter) of each accession rhubarb)

\begin{tabular}{lcccccc}
\hline \multicolumn{1}{c}{ AKSESI } & \multicolumn{7}{c}{ BST KE- } \\
\cline { 2 - 7 } & $\mathrm{I}$ & $\mathrm{II}$ & $\mathrm{III}$ & $\mathrm{IV}$ & $\mathrm{V}$ & $\mathrm{VI}$ \\
\hline JAMU MANGLI & $39.3 \mathrm{~b}$ & $68.32 \mathrm{abc}$ & $87.32 \mathrm{ab}$ & $97.8 \mathrm{ab}$ & $85.14 \mathrm{bcd}$ & $105.84 \mathrm{bc}$ \\
JAMU ADIPURO & $35.34 \mathrm{ab}$ & $82.02 \mathrm{~cd}$ & $84.72 \mathrm{ab}$ & $91.16 \mathrm{a}$ & $120.2 \mathrm{~d}$ & $87.52 \mathrm{a}$ \\
JAMU BUTUH & $39.98 \mathrm{~b}$ & $77.02 \mathrm{bc}$ & $87.82 \mathrm{ab}$ & $101.9 \mathrm{ab}$ & $99.4 \mathrm{~cd}$ & $114.32 \mathrm{e}$ \\
JAMU TLOGODLINGO & $50.02 \mathrm{c}$ & $91.7 \mathrm{~d}$ & $110.38 \mathrm{c}$ & $115.9 \mathrm{c}$ & $122.82 \mathrm{~d}$ & $111.58 \mathrm{~cd}$ \\
JAWA TEMANGGUNG & $32.12 \mathrm{a}$ & $55.92 \mathrm{a}$ & $82.1 \mathrm{ab}$ & $88.96 \mathrm{a}$ & $89.38 \mathrm{abc}$ & $95.6 \mathrm{abc}$ \\
JAWA MANGLI & $35.32 \mathrm{ab}$ & $66.96 \mathrm{ab}$ & $77.12 \mathrm{a}$ & $102.54 \mathrm{ab}$ & $104.18 \mathrm{~d}$ & $113.24 \mathrm{de}$ \\
JAWA ADIPURO & $33.5 \mathrm{ab}$ & $68.82 \mathrm{bc}$ & $83.08 \mathrm{ab}$ & $102.46 \mathrm{ab}$ & $76.94 \mathrm{a}$ & $100.8 \mathrm{abc}$ \\
JAWA BUTUH & $28.4 \mathrm{a}$ & $65.64 \mathrm{ab}$ & $92.84 \mathrm{~b}$ & $107.7 \mathrm{bc}$ & $87.66 \mathrm{~cd}$ & $90.8 \mathrm{ab}$ \\
JAWA WONOSOBO & $29.82 \mathrm{a}$ & $64.22 \mathrm{ab}$ & $85.84 \mathrm{ab}$ & $95.64 \mathrm{ab}$ & $86.62 \mathrm{ab}$ & $92.52 \mathrm{abc}$
\end{tabular}

Keterangan: angka-angka yang diikuti huruf berbeda pada kolom yang sama menunjukkan ada beda nyata pada uji DMRT 0.05 (Description: the numbers followed by different letters in the same column show there is a real difference in the DMRT 0.05 test $)$ 
mempunyai rata-rata tinggi tanaman tertinggi sedangkan kelembak jawa butuh mempunyai rata-rata tinggi tanaman terendah. Pertumbuhan tercepat terjadi pada bulan kedua pengamatan atau 2 bulan setelah tanam. Kemudian pada bulan kelima tinggi tanaman mengalami perlambatan pertumbuhan bahkan sebagian mengalami penurunan tinggi tanaman. mengalami pengguguran daun yang sudah tua. Sehingga ketika dilakukan pengamatan berikutnya, yang diamati adalah daun yang lebih muda sehingga memungkinkan terjadinya penyusutan nilai bentangan (lebar tanaman).

\section{Panjang tangkai daun}

Hasil pengamatan panjang tangkai daun selama 6 bulan dapat dilihat pada tabel 3 .

Tabel 3. Panjang tangkai daun aksesi kelembak (The length of the rhubarb accession stalk) AKSESI BST KE-

\begin{tabular}{lcccccc}
\cline { 2 - 7 } & I & II & III & IV & V & VI \\
\hline JAMU MANGLI & $6.7 \mathrm{bc}$ & $14.7 \mathrm{a}$ & $17.1 \mathrm{ab}$ & $21.72 \mathrm{~b}$ & $26.42 \mathrm{ab}$ & $24.04 \mathrm{abc}$ \\
JAMU ADIPURO & $6.4 \mathrm{~b}$ & $14.12 \mathrm{a}$ & $15.02 \mathrm{a}$ & $16.48 \mathrm{a}$ & $22.42 \mathrm{a}$ & $26.66 \mathrm{bcd}$ \\
JAMU BUTUH & $6.36 \mathrm{~b}$ & $17.36 \mathrm{ab}$ & $17.32 \mathrm{ab}$ & $21.68 \mathrm{~b}$ & $26.56 \mathrm{ab}$ & $24.44 \mathrm{abc}$ \\
JAMU TLOGODLINGO & $7.92 \mathrm{c}$ & $23.56 \mathrm{c}$ & $23.74 \mathrm{c}$ & $25.26 \mathrm{bc}$ & $23.76 \mathrm{ab}$ & $31.52 \mathrm{~d}$ \\
JAWA TEMANGGUNG & $6.04 \mathrm{ab}$ & $14.75 \mathrm{a}$ & $21.54 \mathrm{bc}$ & $22.7 \mathrm{bc}$ & $25.6 \mathrm{ab}$ & $22.26 \mathrm{ab}$ \\
JAWA MANGLI & $6.78 \mathrm{bc}$ & $19.14 \mathrm{~b}$ & $20.98 \mathrm{bc}$ & $25.85 \mathrm{bc}$ & $28.34 \mathrm{ab}$ & $28.78 \mathrm{~cd}$ \\
JAWA ADIPURO & $5.96 \mathrm{ab}$ & $17.36 \mathrm{ab}$ & $21.04 \mathrm{bc}$ & $24.38 \mathrm{bc}$ & $26.1 \mathrm{ab}$ & $20.6 \mathrm{a}$ \\
JAWA BUTUH & $6.58 \mathrm{~b}$ & $16.4 \mathrm{ab}$ & $23.04 \mathrm{c}$ & $27.38 \mathrm{c}$ & $29.66 \mathrm{~b}$ & $22.98 \mathrm{ab}$ \\
JAWA WONOSOBO & $4.82 \mathrm{a}$ & $15.96 \mathrm{ab}$ & $23.28 \mathrm{c}$ & $24.26 \mathrm{bc}$ & $24.38 \mathrm{ab}$ & $24.22 \mathrm{abc}$
\end{tabular}

Keterangan: angka-angka yang diikuti huruf berbeda pada kolom yang sama menunjukkan ada beda nyata pada uji DMRT 0.05 (Description: the numbers followed by different letters in the same column show there is a real difference in the DMRT 0.05 test)

2. Lebar tanaman

Hasil pengamatan lebar tanaman selama 6 bulan pengamatan dapat dilihat pada tabel 2 .

Berdasarkan hasil pengamatan lebar tanaman, pada bulan pertama sampai kelima lebar tanaman kelembak jamu tlogodlingo tertinggi dibanding kelembak lainnya. Pada pengamatan bulan keenam bentangan tanaman terlebar yaitu kelembak jamu butuh. Beberapa aksesi justru mengalami penurunan lebar tanaman (menyempit). Hal ini dikarenakan sifat tanaman kelembak
Berdasarkan hasil analisis di atas panjang tangkai daun terpanjang yaitu kelembak jamu tlogodlingo dan terpendek kelembak jawa adipuro. Tangkai daun mengalami pertumbuhan pesat pada bulan kedua setelah tanam dan selanjutnya pertumbuhan berjalan lambat. Dikarenakan sifat tanaman kelembak yang menggugurkan daun yang telah tua, maka pengamatan tidak dapat dilakukan pada satu tangkai daun. Daun yang diamati adalah daun terbesar yang telah membuka sempurna.

4. Keliling tangkai daun 
Listyana,dkk., KERAGAAN PERTUMBUHAN ...

Tabel 4. Keliling tangkai daun aksesi kelembak $(\mathrm{cm})$ (The circumference of the rhubarb accession stalk $(\mathrm{cm}))$

\begin{tabular}{lcccccc}
\hline \multicolumn{1}{c}{ AKSESI } & \multicolumn{7}{c}{ BST KE- } \\
\cline { 2 - 7 } & $\mathbf{I}$ & $\mathbf{I I}$ & III & IV & V & VI \\
\hline JAMU MANGLI & $1.6 \mathrm{abcd}$ & $2.28 \mathrm{~b}$ & $2.04 \mathrm{~b}$ & $2.44 \mathrm{bc}$ & $2.52 \mathrm{bc}$ & $2.66 \mathrm{bc}$ \\
JAMU ADIPURO & $1.6 \mathrm{ab}$ & $2.2 \mathrm{ab}$ & $2.22 \mathrm{c}$ & $2.3 \mathrm{ab}$ & $2.34 \mathrm{ab}$ & $2.38 \mathrm{ab}$ \\
JAMU BUTUH & $1.72 \mathrm{~cd}$ & $2.16 \mathrm{ab}$ & $1.98 \mathrm{~b}$ & $2.66 \mathrm{c}$ & $2.7 \mathrm{c}$ & $2.9 \mathrm{c}$ \\
JAMU TLOGODLINGO & $1.92 \mathrm{~d}$ & $2.36 \mathrm{~b}$ & $2.04 \mathrm{~b}$ & $2.28 \mathrm{ab}$ & $2.34 \mathrm{ab}$ & $2.52 \mathrm{ab}$ \\
JAWA TEMANGGUNG & $1.48 \mathrm{abc}$ & $2.22 \mathrm{ab}$ & $1.86 \mathrm{a}$ & $2.08 \mathrm{a}$ & $2.16 \mathrm{a}$ & $2.22 \mathrm{a}$ \\
JAWA MANGLI & $1.3 \mathrm{a}$ & $1.98 \mathrm{a}$ & $2.06 \mathrm{~b}$ & $2.35 \mathrm{ab}$ & $2.46 \mathrm{bc}$ & $2.54 \mathrm{ab}$ \\
JAWA ADIPURO & $1.38 \mathrm{ab}$ & $2.16 \mathrm{ab}$ & $1.96 \mathrm{ab}$ & $2.44 \mathrm{bc}$ & $2.5 \mathrm{bc}$ & $2.64 \mathrm{bc}$ \\
JAWA BUTUH & $1.48 \mathrm{~cd}$ & $2.12 \mathrm{ab}$ & $2.06 \mathrm{ab}$ & $2.46 \mathrm{bc}$ & $2.5 \mathrm{bc}$ & $2.68 \mathrm{bc}$ \\
JAWA WONOSOBO & $1.66 \mathrm{abc}$ & $2.1 \mathrm{ab}$ & $1.94 \mathrm{ab}$ & $2.05 \mathrm{a}$ & $2.18 \mathrm{a}$ & $2.28 \mathrm{a}$ \\
\hline
\end{tabular}

Keterangan: angka-angka yang diikuti huruf berbeda pada kolom yang sama menunjukkan ada beda nyata pada uji DMRT 0.05 (Description: the numbers followed by different letters in the same column show there is a real difference in the DMRT 0.05 test $)$

Hasil pengamatan keliling tangkai daun selama 6 bulan dapat dilihat pada tabel 4 .

Berdasarkan hasil pengamatan keliling tangkai daun terbesar yaitu kelembak jamu butuh dan terkecil kelembak jawa temanggung.

5. Jumlah daun
Hasil pengamatan jumlah daun selama 6 bulan pengamatan dapat dilihat pada tabel 5.

Berdasarkan hasil pengamatan di atas jumlah daun terbanyak yaitu kelembak jawa wonosobo dan paling sedikit kelembak jamu adipuro. Kelembak jamu tlogodlingo dan

Tabel 5. Jumlah daun aksesi kelembak (The number of leaves of rhubarb accession)

\begin{tabular}{|c|c|c|c|c|c|c|}
\hline \multirow[t]{2}{*}{ AKSESI } & \multicolumn{6}{|c|}{ BST KE } \\
\hline & I & II & III & IV & $\mathbf{V}$ & VI \\
\hline JAMU MANGLI & $3.6 \mathrm{ab}$ & $21 \mathrm{ab}$ & $23 a b$ & $33.2 b$ & $38.8 \mathrm{bc}$ & $38.4 \mathrm{a}$ \\
\hline JAMU ADIPURO & $3.2 \mathrm{a}$ & $12.6 \mathrm{a}$ & $26.6 a b c$ & $33.4 \mathrm{~b}$ & $22.2 \mathrm{a}$ & $33 \mathrm{a}$ \\
\hline JAMU BUTUH & $3.4 \mathrm{ab}$ & $23.6 \mathrm{ab}$ & $17.2 \mathrm{a}$ & $23 \mathrm{a}$ & $36 \mathrm{bc}$ & $35.2 \mathrm{a}$ \\
\hline JAMU TLOGODLINGO & $3.6 a b$ & $22.6 a b$ & $23.8 \mathrm{ab}$ & $23 \mathrm{a}$ & $27.6 a b$ & $42.4 \mathrm{a}$ \\
\hline JAWA TEMANGGUNG & $4.2 \mathrm{ab}$ & $21.6 \mathrm{ab}$ & $26 a b c$ & $32 b$ & $43 c$ & $42.4 \mathrm{a}$ \\
\hline JAWA MANGLI & $4.4 \mathrm{~b}$ & $30.8 b$ & $34.2 \mathrm{c}$ & $34.8 \mathrm{~b}$ & $31.2 \mathrm{abc}$ & $36 \mathrm{a}$ \\
\hline JAWA ADIPURO & $3.4 \mathrm{ab}$ & $23.6 \mathrm{ab}$ & $19.6 \mathrm{a}$ & $23.6 \mathrm{a}$ & $32.8 \mathrm{abc}$ & $38.6 \mathrm{a}$ \\
\hline JAWA BUTUH & $3.8 \mathrm{ab}$ & $26.6 b$ & $23.2 \mathrm{ab}$ & $28 \mathrm{a}$ & $39.6 \mathrm{bc}$ & $39.4 \mathrm{a}$ \\
\hline JAWA WONOSOBO & $3.33 \mathrm{ab}$ & $26.67 b$ & $29.6 \mathrm{bc}$ & $29 b$ & $27.17 \mathrm{abc}$ & $51.17 \mathrm{~b}$ \\
\hline
\end{tabular}

Keterangan: angka-angka yang diikuti huruf berbeda pada kolom yang sama menunjukkan ada beda nyata pada uji DMRT 0.05 (Description: the numbers followed by different letters in the same column show there is a real difference in the DMRT 0.05 test) 
kelembak jawa wonosobo jumlah daun meningkat pesat pada umur 6 bulan setelah tanam. Sedangkan kelembak jamu mangli, jamu butuh, jawa temanggung dan jawa butuh mengalami penurunan jumlah daun pada umur 6 bulan setelah tanam.

6. Jumlah anakan
Hasil pengamatan jumlah anakan selama 6 bulan pengamatan dapat dilihat pada tabel 6.

Berdasarkan data pengamatan di atas jumlah anakan paling banyak yaitu kelembak jamu tlogodlingo dan paling sedikit kelembak jawa temanggung. Kelembak jamu

Tabel 6. Jumlah anakan aksesi kelembak (Number of rhubarb accession shoots)

\begin{tabular}{|c|c|c|c|c|c|c|}
\hline \multirow[t]{2}{*}{ AKSESI } & \multicolumn{6}{|c|}{ BST KE } \\
\hline & I & II & III & IV & V & VI \\
\hline JAMU MANGLI & $3.02 \mathrm{c}$ & $3.56 \mathrm{a}$ & $9.02 b$ & $4.08 \mathrm{a}$ & $4.3 \mathrm{ab}$ & $4.46 \mathrm{~b}$ \\
\hline JAMU ADIPURO & $0.2 \mathrm{a}$ & $4.6 a b$ & $4.62 \mathrm{a}$ & $4.66 \mathrm{ab}$ & $4.74 b c$ & $5.3 b$ \\
\hline JAMU BUTUH & $2.82 \mathrm{bc}$ & $4.2 \mathrm{ab}$ & $4.04 \mathrm{a}$ & $4.62 \mathrm{ab}$ & $4.74 b c$ & $4.78 b$ \\
\hline JAMU TLOGODLINGO & $1.6 a b c$ & $5.42 b$ & $4.8 \mathrm{a}$ & $4.84 \mathrm{ab}$ & $5.14 \mathrm{c}$ & $5.74 b$ \\
\hline JAWA TEMANGGUNG & $1 . .4 \mathrm{abc}$ & $3.68 \mathrm{ab}$ & $3.9 \mathrm{a}$ & $4.16 \mathrm{a}$ & $4 a$ & $3.58 \mathrm{a}$ \\
\hline JAWA MANGLI & $1.8 \mathrm{abc}$ & $3.64 \mathrm{ab}$ & $3.62 \mathrm{a}$ & $4.025 \mathrm{a}$ & 4.44abc & $4.9 \mathrm{~b}$ \\
\hline JAWA ADIPURO & $2.28 \mathrm{bc}$ & $4.2 \mathrm{ab}$ & $4.36 \mathrm{a}$ & $4.84 \mathrm{ab}$ & $4.06 \mathrm{a}$ & $4.1 \mathrm{~b}$ \\
\hline JAWA BUTUH & $1.8 \mathrm{abc}$ & $3.58 \mathrm{a}$ & $4.14 \mathrm{a}$ & $5.02 b$ & $4.24 \mathrm{ab}$ & $4.2 \mathrm{~b}$ \\
\hline JAWA WONOSOBO & $0.8 \mathrm{ab}$ & $4.1 \mathrm{ab}$ & $3.82 \mathrm{a}$ & $3.88 \mathrm{a}$ & $4.14 \mathrm{ab}$ & $3.74 b$ \\
\hline
\end{tabular}

Keterangan: angka-angka yang diikuti huruf berbeda pada kolom yang sama menunjukkan ada beda nyata pada uji DMRT 0.05 (Description: the numbers followed by different letters in the same column show there is a real difference in the DMRT 0.05 test)

Tabel 7. Panjang daun (cm) aksesi kelembak (long leaf accession rhubarb)

\begin{tabular}{lrrrrrr}
\hline \multicolumn{1}{c}{ AKSESI } & \multicolumn{6}{c}{ BST KE } \\
\cline { 2 - 7 } & \multicolumn{1}{c}{ I } & \multicolumn{1}{c}{ II } & \multicolumn{1}{c}{ III } & \multicolumn{1}{c}{ IV } & \multicolumn{1}{c}{ V } & \multicolumn{1}{c}{ VI } \\
\hline JAMU MANGLI & $14.68 \mathrm{bc}$ & $22.5 \mathrm{ab}$ & $26.46 \mathrm{a}$ & $27.14 \mathrm{ab}$ & $26.62 \mathrm{ab}$ & $26.36 \mathrm{bc}$ \\
JAMU ADIPURO & $15.98 \mathrm{~cd}$ & $32 \mathrm{c}$ & $34.54 \mathrm{~b}$ & $36.42 \mathrm{c}$ & $31.68 \mathrm{bc}$ & $37.84 \mathrm{~d}$ \\
JAMU BUTUH & $15.02 \mathrm{bc}$ & $25.42 \mathrm{~b}$ & $25.96 \mathrm{a}$ & $28.58 \mathrm{ab}$ & $31.46 \mathrm{bc}$ & $29.88 \mathrm{c}$ \\
JAMU TLOGODLINGO & $18.24 \mathrm{~d}$ & $35.18 \mathrm{c}$ & $34.04 \mathrm{~b}$ & $35.98 \mathrm{c}$ & $36 \mathrm{c}$ & $40.44 \mathrm{~d}$ \\
JAWA TEMANGGUNG & $10.98 \mathrm{a}$ & $18.82 \mathrm{a}$ & $22.2 \mathrm{a}$ & $23.06 \mathrm{a}$ & $24.74 \mathrm{a}$ & $20.94 \mathrm{a}$ \\
JAWA MANGLI & $12.78 \mathrm{ab}$ & $21.48 \mathrm{a}$ & $23.78 \mathrm{a}$ & $25.575 \mathrm{ab}$ & $26.74 \mathrm{ab}$ & $26.22 \mathrm{bc}$ \\
JAWA ADIPURO & $11.48 \mathrm{a}$ & $25.42 \mathrm{~b}$ & $25.18 \mathrm{a}$ & $29.54 \mathrm{~b}$ & $25.02 \mathrm{a}$ & $23.46 \mathrm{ab}$ \\
JAWA BUTUH & $11.22 \mathrm{a}$ & $18.8 \mathrm{a}$ & $23.92 \mathrm{a}$ & $27.38 \mathrm{ab}$ & $26.84 \mathrm{ab}$ & $24.68 \mathrm{ab}$ \\
JAWA WONOSOBO & $11.42 \mathrm{a}$ & $19.58 \mathrm{a}$ & $23.76 \mathrm{a}$ & $25.68 \mathrm{ab}$ & $25.32 \mathrm{a}$ & $23.82 \mathrm{ab}$
\end{tabular}

Keterangan: angka-angka yang diikuti huruf berbeda pada kolom yang sama menunjukkan ada beda nyata pada uji DMRT 0.05 (Description: the numbers followed by different letters in the same column show there is a real difference in the DMRT 0.05 test $)$ 
mempunyai jumlah anakan yang relati lebih banyak dibanding dengan kelembak jawa.

7. Panjang daun

Hasil pengamatan panjang daun selama 6 bulan pengamatan dapat diihat pada tabel 7.

Berdasarkan data pengamatan daun panjang karena bentuk daun pada kelembak jamu meruncing sedangkan pada kelembak jawa bentuk daunnya membulat.

8. Lebar daun

Hasil pengamatan lebar daun selama 6 bulan pengamatan dapat dilihat pada tabel 8.

Tabel 8. Lebar daun (cm) aksesi kelembak (Leaf width (cm) accession rhubarb)

\begin{tabular}{lrrrrrr}
\hline \multicolumn{1}{c}{ AKSESI } & \multicolumn{7}{c}{ BST KE } \\
\cline { 2 - 7 } & \multicolumn{1}{c}{$\mathrm{I}$} & \multicolumn{1}{c}{$\mathrm{II}$} & \multicolumn{1}{c}{ III } & \multicolumn{1}{c}{ IV } & \multicolumn{1}{c}{ V } & \multicolumn{1}{c}{ VI } \\
\hline JAMU MANGLI & $18.48 \mathrm{bc}$ & $27.08 \mathrm{ab}$ & $25.82 \mathrm{a}$ & $32.2 \mathrm{ab}$ & $30.24 \mathrm{a}$ & $32.24 \mathrm{c}$ \\
JAMU ADIPURO & $18.52 \mathrm{bc}$ & $39.38 \mathrm{c}$ & $42.88 \mathrm{c}$ & $46.88 \mathrm{~d}$ & $33 \mathrm{a}$ & $35.28 \mathrm{c}$ \\
JAMU BUTUH & $19.16 \mathrm{c}$ & $31.12 \mathrm{abc}$ & $29.48 \mathrm{ab}$ & $31.64 \mathrm{ab}$ & $34.56 \mathrm{a}$ & $34.04 \mathrm{c}$ \\
JAMU TLOGODLINGO & $22.72 \mathrm{~d}$ & $35.64 \mathrm{bc}$ & $36.34 \mathrm{bc}$ & $39.9 \mathrm{c}$ & $35.72 \mathrm{a}$ & $40.62 \mathrm{~d}$ \\
JAWA TEMANGGUNG & $13.64 \mathrm{a}$ & $23.8 \mathrm{a}$ & $25.76 \mathrm{a}$ & $27.96 \mathrm{a}$ & $29.12 \mathrm{a}$ & $25.12 \mathrm{a}$ \\
JAWA MANGLI & $16.76 \mathrm{abc}$ & $29.06 \mathrm{ab}$ & $31.44 \mathrm{ab}$ & $31.05 \mathrm{ab}$ & $35.68 \mathrm{a}$ & $35.56 \mathrm{c}$ \\
JAWA ADIPURO & $16.24 \mathrm{abc}$ & $31.12 \mathrm{abc}$ & $27.82 \mathrm{a}$ & $36.76 \mathrm{bc}$ & $30.5 \mathrm{a}$ & $30.42 \mathrm{bc}$ \\
JAWA BUTUH & $15.54 \mathrm{ab}$ & $24.7 \mathrm{a}$ & $32.66 \mathrm{ab}$ & $35.3 \mathrm{abc}$ & $33.18 \mathrm{a}$ & $30.52 \mathrm{bc}$ \\
JAWA WONOSOBO & $15.56 \mathrm{ab}$ & $28.3 \mathrm{ab}$ & $30.42 \mathrm{ab}$ & $32.6 \mathrm{abc}$ & $30.12 \mathrm{a}$ & $26.94 \mathrm{ab}$
\end{tabular}

Keterangan: angka-angka yang diikuti huruf berbeda pada kolom yang sama menunjukkan ada beda nyata pada uji DMRT 0.05 (Description: the numbers followed by different letters in the same column show there is a real difference in the DMRT 0.05 test)

Tabel 9. Hasil pengamatan warna daun kelembak dari berbagai aksesi (Result of observation color of rhubarb leaf from various accession)

\begin{tabular}{|c|c|c|c|c|c|}
\hline AKSESI & INDIVIDU 1 & INDIVIDU 2 & INDIVIDU 3 & INDIVIDU 4 & INDIVIDU 5 \\
\hline JAMU MANGLI & HIJAU & HIJAU & HIJAU & HIJAU & HIJAU \\
\hline JAMU ADIPURO & HIJAU & HIJAU & HIJAU & HIJAU & HIJAU \\
\hline JAMU BUTUH & HIJAU & HIJAU & HIJAU & HIJAU & HIJAU \\
\hline $\begin{array}{l}\text { JAMU } \\
\text { TLOGODLINGO }\end{array}$ & HIJAU & HIJAU & HIJAU & HIJAU & HIJAU \\
\hline $\begin{array}{l}\text { JAWA } \\
\text { TEMANGGUNG }\end{array}$ & HIJAU & HIJAU & HIJAU & HIJAU & HIJAU \\
\hline JAWA MANGLI & HIJAU & HIJAU & HIJAU & HIJAU & HIJAU \\
\hline JAWA ADIPURO & HIJAU & HIJAU & HIJAU & HIJAU & HIJAU \\
\hline JAWA BUTUH & HIJAU & HIJAU & HIJAU & HIJAU & HIJAU \\
\hline JAWA WONOSOBO & HIJAU & HIJAU & HIJAU & HIJAU & HIJAU \\
\hline
\end{tabular}

terpanjang yaitu kelembak jamu tlogodlingo dan terpendek kelembak jawa temanggung. Kelembak jamu mempunyai daun yang lebih
Berdasarkan data pengamatan daun terlebar yaitu kelembak jamu tlogodlingo dan terkecil kelembak jawa temanggung 
9. Warna daun

Hasil pengamatan terhadap warna daun dapat dilihat pada tabel 9 di bawah ini.

Berdasarkan data pengamatan pada tabel 9 seluruh sampel yang diamati mempunyai warna daun hijau.

10. Warna tangkai daun

Hasil pengamatan terhadap warna tangkai daun dapat dilihat pada tabel 10 di bawah ini. varian yaitu kelembak jamu yang digunakan sebagai bahan baku jamu dan kelembak rokok yang digunakan utnuk bahan baku rokok. Kedua varian kelembak tersebut mempunyai perbedaan morfologi terutama pada bagian daun dan umbi. Keragaan pertumbuhan menunjukkan seluruh aksesi kelembak Jamu lebih tinggi dibandingkan dengan kelembak Jawa. Hal tersebut terkait dengan ukuran daun dan umbi kelembak Jamu yang lebih besar.

Tabel 10. Warna tangkai daun beberapa aksesi kelembak (The color of the rod leaves some accession rhubarb)

\begin{tabular}{llllll}
\hline \multicolumn{1}{c}{ AKSESI } & INDIVIDU 1 & INDIVIDU 2 & INDIVIDU 3 & INDIVIDU 4 & INDIVIDU 5 \\
\hline JAMU MANGLI & HIJAU MERAH & MERAH & HIJAU MERAH & HIJAU MERAH & MERAH \\
JAMU ADIPURO & HIJAU & HIJAU MERAH & HIJAU MERAH & HIJAU MERAH & HIJAU \\
JAMU BUTUH & HIJAU MERAH & HIJAU MERAH & HIJAU MERAH & HIJAU MERAH & $\begin{array}{l}\text { HIJAU } \\
\text { MERAH }\end{array}$ \\
JAMU & & & & & HIJAU MERAH \\
TLOGODLINGO & HIJAU & HIJAU MERAH & HIJAU MERAH & HIJAU \\
JAWA & MERAH & MERAH & HIJAU MERAH & MERAH & HIJAU \\
TEMANGGUNG & MERAH & MERAH & MERAH & MERAH HIJAU & MERAH \\
JAWA MANGLI & HIJAU & HIJAU MERAH & HIJAU MERAH & HIJAU MERAH & HIJAU \\
JAWA ADIPURO & HIJAU MERAH & HIJAU & HIJAU & HIJAU & HIJAU \\
JAWA BUTUH & HIJAU MERAH & MERAH & HIJAU & MERAH & HIJAU \\
JAWA WONOSOBO & MERAH & MERAH \\
\hline
\end{tabular}

Berdasarkan tabel 10 diatas tangkai daun untuk sampel kelembak yang diamati memiliki warna yang bervariasi mulai dari hijau, hijau merah hingga merah. Kelembak yang ditanam oleh masyarakat sebanyak 2
Menurut Kantor Informasi Penyuluhan Pertanian dan Kehutanan Kabupaten Magelang, kelembak Jamu dan kelembak jawa dapat dibedakan dari karakter morfologi disajikan pada Tabel 11 : 
Listyana,dkk., KERAGAAN PERTUMBUHAN ...

Tabel 11. Karakter Morfologi Kelembak Jamu Dan Kelembak Jawa

\begin{tabular}{lll}
\hline & Kelembak Jawa & Kelembak Jamu \\
\hline Daun & warna hijau sampai hijau & warna kekuningan, lebar, panjang, \\
& kekuningan, bentuk agak & meruncing pada bagian ujungnya, ada \\
& bulat, ujung tumpul & tanda warna merah keunguan pada \\
& mendekati bulat & pangkal tangkai daun \\
Tangkai daun & warna hijau, berambut halus, & warna didominasi merah keunguan, \\
& lengkungan pada sisi tangkai & tidak berbulu, ada lengkungan pada \\
& tidak nyata & tangkai \\
Mata tunas & Sedikit & Banyak \\
\hline
\end{tabular}

Berdasarkan hasil penelitian, beberapa aksesi mengalami perubahan secara morfologi. Antara lain, kelembak jawa yang memiliki lebar tanaman melebihi kelembak jamu. Tangkai daun kelembak jawa yang semula berwarna putih saat ditanam di daerah asal sebagian berubah menjadi berwarna putih merah atau bahkan merah yang merupakan ciri dari kelembak jamu. Menurut (Handayani, et al., 2013) perubahan morfologi tanaman dapat dipengaruhi oleh lingkungan berupa suhu lingkungan yang tinggi yang melebihi suhu optimum yang dibutuhkan oleh tanaman tersebut. Sedangkan menurut (Suharti \& Gusmalawati, 2017) perubahan morfologi dapat terjadi karena pengaruh cekaman kekeringan. Menurut (Bratsch, 2009) suhu optimal untuk kelembak yaitu antara $15-20^{\circ} \mathrm{C}$. Sedangkan suhu ratarata di Tlogodlingo Tawangmangu adalah 26, $1^{\circ} \mathrm{C}$ (Aryani, 2017). Dengan tingginya suhu di Tawangmangu memungkinkan terjadinya perubahan morfologi tanaman kelembak yang dibudidayakan di Tawangmangu.

Sedangkan menurut (Setiawan \& Sukamto, 2016) pemberian naungan juga dapat menyebabkan perubahan morfologi pada tanaman nilam. Tanaman yang tumbuh di bawah naungan tumbuh lebih tinggi dan mempunyai jumlah helaian daun yang lebih banyak dibandingkan tanaman yang tumbuh tanpa naungan. Tanaman kelembak yang dibudidayakan di Tawangmangu, pada awalnya sebagian ditanam di bawah naungan pohon dan sebagian tanpa naungan sehingga memungkinkan terjadi perubahan morfologi sebelum kelembak diperbanyak untuk dibudidayakan.

\section{KESIMPULAN}

Sembilan aksesi kelembak terbagi menjadi 2 varian yaitu kelembak jamu dan kelembak jawa yang kemudian ditanam pada lokasi yang sama menunjukkan pertumbuhan yang berbeda. Kelembak jamu menunjukkan 
pertumbuhan yang lebih tinggi $(40.14 \mathrm{~cm}-$ $58.12 \mathrm{~cm})$ dibanding kelembak jawa (33.24 $\mathrm{cm}-48.16 \mathrm{~cm})$.

\section{UCAPAN TERIMA \\ (ACKNOWLEDGEMENT)}

KASIH

Penulis mengucapkan terima kasih kepada

Kepala Balai Besar Penelitian dan Pengembangan Tanaman Obat dan Obat Tradisional yang telah memfasilitasi penelitian ini.

\section{DAFTAR PUSTAKA}

Ahmad, S. B., Parrah, J., Mir, M. u. R. \& Tiwari, B., 2013. Rhubarb: The Wondrous Drug. A Review. International Journal of Pharmacy and Biological Sciences, 3(3), pp. 228-233.

An Zhao, X. et al., 2018. Emodin Alleviates Liver Fibrosis of Mice by Reducing Infiltration of Gr1hi Monocytes. EvidenceBased Complementary and Alternative Medicine.

Aryani, I., 2017. Studi Keanekaragaman Spermatophyta di Perbukitan Daerah Tlogodlingo Kecamatan Tawangmangu Kabupaten Karanganyar. s.1., s.n., pp. 109113.

Bratsch, A., 2009. Virginia Cooperative Extension.

[Online]

Available at: https://pubs.ext.vt.edu/content/dam/pubs_e xt_vt_edu/438/438-110/438-110_pdf.pdf

Cui, H. et al., 2017. Emodin Alleviates Severe Acute Pancreatitis-Associated Acute Lung Injury By Decreasing Pre-B-Cell ColonyEnhancing Factor Expression And Promoting Polymorphonuclear Neutrophil Apoptosis. Molecular Medicine Reports, Oktober, 16(4), pp. 5121-5128.

Dong, X., Yin, X., Fu, J. \& Cao, S., 2016. Emodin: A Review of its Pharmacology, Toxicity and Pharmacokinetics. Phytotherapy Research, Mei, 30(8), pp. 1207-1218.
Fu Lin, W., Wang, C. \& Quan Ling, C., 2015. Research Progress In Anti-Tumor Effect Of Emodin. Zhongguo Zhong Yao Za Zhi, Oktober, 40(20), pp. 3937-3940.

Handayani, T., Basunanda, P., Murti, R. \& Sofiari, E., 2013. Perubahan Morfologi dan Toleransi Tanaman Kentang Terhadap Suhu Tinggi. Jurnal Hortikultura, 23(4), pp. 318-328.

Kementerian Kesehatan RI, 2012. Vademekum Tanaman Obat Untuk Saintifikasi Jamu Jilid III. Jakarta: Kementerian Kesehatan.

Kuhl, J. C. \& DeBoer, V. L., 2008. Genetic Diversity of Rhubarb Cultivars. Journal of the American Society for Horticultural Science, Juli, 133(4), pp. 587-592.

Ling Yin, L., Jun Tang, L., Zhi Ye, Z. \& Guo, L., 2018. Effect Of Rhubarb On Neonatal Rats With Bronchopulmonary Dysplasia Induced By Hyperoxia. Zhongguo Dang Dai Er Ke Za Zhi, Mei, 20(5), pp. 410-415.

Lu, Z. et al., 2015. Rhubarb Enema Attenuates Renal Tubulointerstitial Fibrosis in 5/6 Nephrectomized Rats by Alleviating Indoxyl Sulfate Overload. PLoS ONE, Desember.10(12).

Setiawan \& Sukamto, 2016. Karakter Morfologis dan Fisiologis Tanaman Nilam di Bawah Naungan dan Tanpa Naungan. Buletin Littro, 27(2), pp. 137-146.

Sheng, F. X. et al., 2011. Progress in research of chemical constituents and pharmacological actions of Rhubarb. Chinese Journal of New Drugs, pp. 15341538.

Suharti, M. \& Gusmalawati, D., 2017. Struktur Anatomi Akar, Batang dan Daun Gaharu (Aquilaria malaccensis Lamk.) yang Mengalami Cekaman Kekeringan. Protobiont, 6(2), pp. 38-44.

Wei, G. et al., 2017. Effect of Emodin on Preventing Postoperative Intra-Abdominal Adhesion Formation. Oxidative Medicine and Cellular Longevity, Agustus.

Xian Dong, M. et al., 2009. Emodin Protects Rat Liver From Ccl4-Induced Fibrogenesis Via Inhibition Of Hepatic Stellate Cells Activation. World Journal Of Gastroentrology, Oktober, 15(38), pp. 4753-4762. 
Yao, P., Li, Y., Cui, M. \& Deng, Y., 2015. Effects of Rhubarb on Intestinal Flora and Toll-Like Receptors of Intestinal Mucosa in Rats With Severe Acute Pancreatitis. Pancreas, April.44(5).

Yasha, R. \& Prihartiningsih, 2012. Pengaruh Pemberian Ekstrak Akar Kelembak (Rheum Officinale Baill) Terhadap Jumlah Sel Fibroblas Pada Penyembuhan Luka Gingiva Tikus Wistar. Yogyakarta: s.n.

Zhao N, et al., 2014. Metabolomics analysis revealing multiple compounds changed in rhubarb after processing. Zhongguo Zhong Yao Za Zhi., Mei, 39(9), pp. 1607-1613. 